\title{
Corporate Social Responsibility and Cash Holdings
}

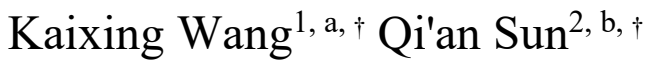

\author{
${ }^{1}$ Kogod School of Business, American University, Washington, District of Columbia 20016, US \\ ${ }^{2}$ Beijing Institute of Technology, Beijing, Beijing 100000, China \\ ${ }^{a} k w 8365 a @ s t u d e n t . a m e r i c a n . e d u,{ }^{b 1120182016 @ b i t . e d u . c n ~}$ \\ ${ }^{\dagger}$ These authors contributed equally.
}

\begin{abstract}
In this paper, we focus on discussing the relationship between corporate social responsibility and cash holdings in China stock market. We can draw conclusions based on corporate social responsibility in China's domestic enterprises, the value of corporate cash holdings and corporate cash holdings for the influence of corporate social responsibility. That is, the improvement of social responsibility can significantly lower the value of enterprises and cash holdings. Nonstate-owned corporate cash holdings in the value of social responsibility mechanism of performance are particularly prominent. The proposed method to solve the problem is to use hypothetical and empirical methods to prove the relationship between corporate social responsibility and cash holdings. The results obtained in this research include that research on the relationship between optimal cash holding and corporate social responsibility. It is found that the level of corporate cash holding will be reflected in the improvement of corporate social responsibility performance. It is believed that enterprises with high corporate social responsibility have a better reputation and public praise and can better obtain financing, so they tend to have low cash holdings, reducing the cost of cash holdings and financing. Corporate social responsibility and corporate cash holdings are substitutes for each other.
\end{abstract}

Keywords: China, corporate social responsibility, cash holdings, domestic enterprises, non-state-owned enterprise.

\section{INTRODUCTION}

The research on corporate social responsibility (hereafter, CSR) in China began in the 1980s, which originated from the promotion of international trade and multinational corporations in the practice of reform and opening up. Chinese enterprises' understanding of social responsibility stems from moral and cultural experience [1]. The core meaning of CSR is that enterprises should undertake social responsibilities while pursuing profits and fulfilling their corporate citizens' obligations.

As the most liquid asset in a corporate, the level of cash holdings can reflect a company's financial and business strategy. Studies have found that the important factors determining cash holdings are firms' growth opportunities, cash flows, liquid assets, leverage, and bank debt. And firm heterogeneity and endogeneity are crucial in analyzing the cash structure of firms [2]. Firms with strong growth opportunities and higher risk cash flows hold relatively high cash ratios to total non-cash assets. Firms with the greatest access to the capital markets, such as big enterprises and those with high credit ratings, tend to hold lower ratios of cash to total non-cash assets [3]. For the research of cash holdings in China, there are about the relationship between principalprincipal conflicts and cash holdings [4], the effect of political uncertainty on cash holdings [5], and others focus on the impact of imperfections in China's emerging markets on cash holdings.

Only when the fulfillment of social responsibility can bring sustained enterprise value growth in the short or long term, the profit-oriented enterprise will invest resources to fulfill corporate social responsibility. Therefore, it is of great importance to clarify the mechanism of the impact of CSR fulfillment on corporate value. CSR fulfillment can improve the corporate image and win the public's goodwill and trust as a positive corporate behavior. Then, whether the realization of CSR can relieve enterprises' financing constraints and then make enterprises reduce their cash holdings indirectly affect the cash holdings level.

We focus on the Chinese market and Chinese listed companies for the reasons below. First, China is a fastgrowing emerging market with many challenging and 
opportunities. This research can push the firms' concern about the value of CSR and bring revenue for them. Second, the new market means there is an imperfection. We are easier to make a hypothesis and to explore the relationship between them. Third, CSR started late in China, and its disclosure is not quite necessary. There is no law to supervise CSR behavior. This research can cause enterprises and governments to pay more attention to the fulfillment of CSR.

Using the sample of 15042 China-listed companies' data from 2011 to 2018, the article explores the relationship between CSR value and the firm's cash holdings. We construct a panel fixed effect model, and the empirical results show that the high CSR value can reduce the firm's cash holdings. To further exclude the impact of potential endogeneity in this article, we conducted robustness checks, considering the firm's fixed effect, changing the cash holdings counting methods, and considering the time lag. After the above robustness checks, our results continue to hold. And in conclusion, we find under the negative correlation between CSR and cash holdings, it is more significant in small size companies, high return or low leverage firms.

The main research contributions of this paper are as follows:

(1) Through the analysis of the impact path of CSR fulfillment on the cash holding level, the mechanism of CSR fulfillment has been clarified. The scope of factors affecting the cash holding level has been expanded, and further incremental evidence has been added for relevant literature in this field.

(2) Due to CSR performance, improving the financing constraint conditions to reduce the level of cash holdings has affected the allocation of enterprise resources. Therefore, they can undertake social responsibility construction enterprises to actively, improving the quality of social responsibility to fulfill, optimize the market mechanism, give full play to the CSR to fulfill the strategic role of resource distribution, and thus increase the market resources allocative efficiency.

(3) Since the 1990s, research on CSR has been introduced and developed rapidly in China. The relevant research in China started from the introduction of foreign results. There are many review articles or materials related to the research and development of CSR in foreign countries. There are also some thematic reviews, but few summarize CSR's overall research status and development in China.

\section{HYPOTHESIS DEVELOPMENT}

Scholarship on CSR is a broad area that many scholars and institutions had researched. Extant studies have interpreted the impact of CSR on firms' idiosyncratic risk [6,7]. And riskier firms to accumulate higher cash reserves [8]. However, a higher CSR enterprise means better internal governance and better risk control. So, we can assume a relationship between cash holdings, idiosyncratic risk, and CSR. And we finally put up this hypothesis:

Hypothesis: The higher CSR value can significantly lower the cash holdings.

\section{RESEARCH DESIGN}

\subsection{Data:}

The main data used in our empirical analysis come from China Stock Market \& Accounting Research (CSMAR) database. We choose 15042 listed companies in the Chinese stock market and obtain the CSR information, including shareholders, employees, suppliers, and environmental liability. We also focus on the audit data of them and adapt the data of book-tomarket rate, lever ratio, return on assets, etc., to measure the cash flow of the individual company. We noticed that whether the company is a state-owned enterprise is also an important factor. We acquire corresponding data from CSMAR range from 2011-2018. We do the shrinking tail and other data processes.

\subsection{Construction of Variables:}

Among all assets, cash is the most liquid and relatively easy to measure, in the former research, most of them used cash holdings to measure the liquidity of a firm. Based on this way, the article defines cash holdings as monetary capital divided by net worth of total assets minus monetary capital.

$$
\frac{\text { Monetary Capital }}{\text { Total Assets - Monetary Capital }}
$$

\subsection{Model Specification:}

$$
\begin{aligned}
& \text { Cashflow }_{i, t+1}=\beta_{0}+\beta_{1} * \operatorname{CSR}_{i, t}+\sum_{k} Y_{k} \text { Control }_{k, i, t}+ \\
& \quad \text { Year, } \text { Industry fixed effects }+\varepsilon_{i, t}
\end{aligned}
$$

Where Cashflow $_{i, t+1}$ is the cashflow of researched companies in the next year due to the cashflow cannot show its manifestation immediately. And we need to observe the data in the second year. $C S R_{i, t}$ is the cooperate social responsibility value in year $t$. Control $_{k, i, t}$ is the set of control variables that defined at the above section. To mitigate potential problems that may arise from the deviation of omitting time-invariant and industry-specific characteristics, we also use this model to control the year fixed effects and industry fixed effects. 


\section{EMPIRICAL RESULTS}

\subsection{Descriptive Statistics:}

Table1: Descriptive Statistics

\begin{tabular}{llllll}
\hline VARIABLE & Observation & Mean & $\begin{array}{l}\text { Standard } \\
\text { Deviation }\end{array}$ & Min & Max \\
\hline CASH HOLDING & 15042 & 0.113 & 0.153 & 0.000 & 0.842 \\
CSR & 15042 & 0.024 & 0.015 & -0.003 & 0.074 \\
SIZE & 15042 & 22.511 & 1.125 & 20.579 & 26.186 \\
TOBIN & 15042 & 2.046 & 1.142 & 0.915 & 7.236 \\
ROA & 15042 & 0.047 & 0.049 & -0.164 & 0.189 \\
LEV & 15042 & 0.374 & 0.198 & 0.043 & 0.840 \\
BOARD & 15042 & 2.130 & 0.197 & 1.609 & 2.708 \\
\hline
\end{tabular}

Table 1 provides descriptive statistics for the variables used in our analysis. The means of the crash holdings and CSR value 0.114 and 0.024 , respectively. The firms in our sample have an average size of 22.510 with a mean ROA is 0.048 , leverage is 0.375 . The mean of board size is 2.130. This is consistent with the actual situation of uneven disclosure of CSR and other data in
China based on CSMAR database. At the same time, the statistical results of other control variables are in the normal range. The max standard deviation is less than 10 , there is no multicollinearity.

\subsection{Multivariate Analysis:}

Table2: Multivariate Analysis

\begin{tabular}{|c|c|c|c|c|c|c|c|c|c|c|c|c|c|c|c|c|c|c|}
\hline $\begin{array}{c}\text { CASH } \\
\text { HOLDING }\end{array}$ & \multicolumn{6}{|c|}{1} & \multicolumn{6}{|c|}{2} & \multicolumn{6}{|c|}{3} \\
\hline VARIABLE & $\begin{array}{l}\text { Co } \\
\text { ef. }\end{array}$ & $\begin{array}{l}\text { Std } \\
\text { Err }\end{array}$ & $\mathbf{z}$ & $\begin{array}{c}\mathbf{P}>1 \\
\mathbf{z} \mid\end{array}$ & \multicolumn{2}{|c|}{$\begin{array}{c}{[95 \%} \\
\text { Conf. } \\
\text { Interval] }\end{array}$} & $\begin{array}{l}\text { Co } \\
\text { ef. }\end{array}$ & $\begin{array}{l}\text { Std } \\
\dot{\text { Err }}\end{array}$ & $\mathbf{z}$ & $\begin{array}{c}\mathbf{P}>1 \\
\mathbf{z} \mid\end{array}$ & \multicolumn{2}{|c|}{$\begin{array}{c}{[95 \%} \\
\text { Conf. } \\
\text { Interval] }\end{array}$} & $\begin{array}{l}\text { Co } \\
\text { ef. }\end{array}$ & $\begin{array}{l}\text { Std } \\
\text { Err }\end{array}$ & $\mathbf{z}$ & $\begin{array}{c}\mathbf{P}>1 \\
\mathbf{z} \mid\end{array}$ & \multicolumn{2}{|c|}{$\begin{array}{c}{[95 \%} \\
\text { Conf. } \\
\text { Interval] }\end{array}$} \\
\hline CSR & $\begin{array}{l}- \\
0.2 \\
95\end{array}$ & $\begin{array}{c}0.1 \\
10\end{array}$ & $\begin{array}{l}- \\
2.6 \\
70\end{array}$ & $\begin{array}{l}0.0 \\
08\end{array}$ & $\begin{array}{l}- \\
0.5 \\
11\end{array}$ & $\begin{array}{l}- \\
0.0 \\
79\end{array}$ & $\begin{array}{l}- \\
0.1 \\
80\end{array}$ & $\begin{array}{l}0.0 \\
99\end{array}$ & $\begin{array}{c}- \\
1.81 \\
0\end{array}$ & $\begin{array}{l}0.0 \\
70\end{array}$ & $\begin{array}{l}- \\
0.3 \\
74\end{array}$ & $\begin{array}{l}0.0 \\
15\end{array}$ & $\begin{array}{l}- \\
0.2 \\
05\end{array}$ & $\begin{array}{l}0.0 \\
94\end{array}$ & $\begin{array}{c}- \\
2.19 \\
0\end{array}$ & $\begin{array}{l}0.0 \\
29\end{array}$ & $\begin{array}{c}- \\
0.3 \\
90\end{array}$ & $\begin{array}{c}- \\
0.0 \\
21\end{array}$ \\
\hline SIZE & & & & & & & $\begin{array}{l}- \\
0.0 \\
28\end{array}$ & $\begin{array}{l}0.0 \\
02\end{array}$ & $\begin{array}{c}- \\
13.9 \\
70\end{array}$ & $\begin{array}{l}0.0 \\
00\end{array}$ & $\begin{array}{l}- \\
0.0 \\
32\end{array}$ & $\begin{array}{c}- \\
0.0 \\
24 \\
\end{array}$ & $\begin{array}{c}- \\
0.0 \\
16\end{array}$ & $\begin{array}{l}0.0 \\
02\end{array}$ & $\begin{array}{c}- \\
8.54 \\
0\end{array}$ & $\begin{array}{l}0.0 \\
00\end{array}$ & $\begin{array}{c}- \\
0.0 \\
19 \\
\end{array}$ & $\begin{array}{c}- \\
0.0 \\
12 \\
\end{array}$ \\
\hline ROA & & & & & & & $\begin{array}{l}0.0 \\
37\end{array}$ & $\begin{array}{l}0.0 \\
27\end{array}$ & $\begin{array}{c}1.38 \\
0\end{array}$ & $\begin{array}{l}0.1 \\
67\end{array}$ & $\begin{array}{l}- \\
0.0 \\
16\end{array}$ & $\begin{array}{l}0.0 \\
90\end{array}$ & $\begin{array}{l}0.1 \\
28\end{array}$ & $\begin{array}{l}0.0 \\
25\end{array}$ & $\begin{array}{c}5.11 \\
0\end{array}$ & $\begin{array}{l}0.0 \\
00\end{array}$ & $\begin{array}{l}0.0 \\
79\end{array}$ & $\begin{array}{l}0.1 \\
77\end{array}$ \\
\hline LEV & & & & & & & $\begin{array}{l}- \\
0.2 \\
20\end{array}$ & $\begin{array}{l}0.0 \\
12 \\
\end{array}$ & $\begin{array}{c}- \\
17.7 \\
90\end{array}$ & $\begin{array}{l}0.0 \\
00\end{array}$ & $\begin{array}{l}- \\
0.2 \\
44\end{array}$ & $\begin{array}{c}- \\
0.1 \\
95\end{array}$ & $\begin{array}{c}- \\
0.2 \\
69\end{array}$ & $\begin{array}{c}0.0 \\
12 \\
\end{array}$ & $\begin{array}{c}- \\
22.4 \\
90\end{array}$ & $\begin{array}{l}0.0 \\
00\end{array}$ & $\begin{array}{c}- \\
0.2 \\
92\end{array}$ & $\begin{array}{c}- \\
0.2 \\
46\end{array}$ \\
\hline TOBIN & & & & & & & & & & & & & $\begin{array}{c}- \\
0.0 \\
45\end{array}$ & $\begin{array}{l}0.0 \\
01\end{array}$ & $\begin{array}{c}- \\
31.0 \\
70\end{array}$ & $\begin{array}{l}\text { 0.0 } \\
00 \\
\end{array}$ & $\begin{array}{c}- \\
0.0 \\
49\end{array}$ & $\begin{array}{c}- \\
0.0 \\
43 \\
\end{array}$ \\
\hline BOARD & & & & & & & & & & & & & $\begin{array}{l}\mathbf{0 . 0} \\
03\end{array}$ & $\begin{array}{c}0.0 \\
08\end{array}$ & $\begin{array}{c}0.37 \\
0\end{array}$ & $\begin{array}{l}0.7 \\
11\end{array}$ & $\begin{array}{c}- \\
0.0 \\
13\end{array}$ & $\begin{array}{l}0.0 \\
20\end{array}$ \\
\hline YEAR FE & \multicolumn{6}{|c|}{ YES } & \multicolumn{6}{|c|}{ YES } & \multicolumn{6}{|c|}{ YES } \\
\hline $\begin{array}{c}\text { R- } \\
\text { SQUARED }\end{array}$ & \multicolumn{6}{|c|}{0.310} & \multicolumn{6}{|c|}{0.383} & \multicolumn{6}{|c|}{0.441} \\
\hline $\begin{array}{c}\text { OBSERVAT } \\
\text { IONS }\end{array}$ & \multicolumn{6}{|c|}{15042} & \multicolumn{6}{|c|}{15042} & \multicolumn{6}{|c|}{15042} \\
\hline
\end{tabular}

The independent variables analyzed below are CSR and corporate cash holdings, while the dependent variable is corporate cash holdings. In addition to these two variables, we also considered other potentially confounding variables. For example, the cooperate social responsibility value $(C S R)$, the value of logarithmic (SIZE), return on assets $(R O A)$, Tobin Q value (TOBIN) and leverage $(L E V)$, the scale of the board of directors $(B O A R D)$. As mentioned above, we standardized the variables to remove the dimensions of variables before regression. In Table 2, we report the results of regression models on the impact on cashflow based by the cooperate social responsibility. The table shows OLS regression results, where all control variables are excluded, we find that the CSR and cash holdings are relatively positive $(1.067$ with $t$-value $=13.64)$. Taken together, the result implies that there is a strong negative correlation between CSR and the firm's cash holdings. At the same 
time, the result on the control variables is relatively consistent with prior studies [9]. For example, firms with better CSR value tend to have a lower cash holding. Considering the interaction between processing variables and propensity values. The results show that the interaction between cash return and propensity value is not significant. Therefore, only from the perspective of regression model interaction terms there is no case that the processing effect changes with the change of propensity value. Then we do the robust test.

\subsection{Robustness Test}

\subsubsection{Individual fixed benefit}

In this paper, the calculation method of CSR and cash holdings is adopted by income standardization, which is defined as the proportion of CSR and the percentage of cash holdings, respectively, and the first table is established. Then create a second table and compare it with the first table. The results showed that the regression coefficient level of the score of CSR was significant. The conclusions brought by this data have no negative impact on this paper.

\subsubsection{Change the dependent variable (Y: Cash holding)}

This paper uses other methods such as machine learning, text analysis, and semantic reference to extract the creativity of enterprises and establishes the quality index to measure the proportion of enterprises' social responsibility and cash holdings by measuring the innovation patents of enterprises in China. The results show that no matter how the dependent variables change, the regression coefficients of cash holding are all significantly positive. In contrast, the regression coefficients of CSR are all negative. The above results are consistent with the research conclusions of this paper.

\subsubsection{Lagged items}

Table 3: Robustness Test

\begin{tabular}{lccc}
\hline VARIABLES & 1 & 2 & 3 \\
\hline CSR & $-0.275^{* * *}$ & $-0.257^{* *}$ & $-0.252^{* *}$ \\
SIZE & $(-2.623)$ & $(-2.284)$ & $(-2.283)$ \\
& $-0.028^{* * *}$ & $-0.026^{* * *}$ & $-0.026^{* * *}$ \\
TOBIN & $(-5.369)$ & $(-4.802)$ & $(-4.740)$ \\
& $-0.042^{* * *}$ & $-0.042^{* * *}$ & $-0.041^{* * *}$ \\
ROA & $(-18.942)$ & $(-17.284)$ & $(-17.167)$ \\
& $0.104 * * *$ & $0.113 * * *$ & $(3.086)$ \\
LEV & $(3.155)$ & $(3.246)$ & $-0.299^{* * *}$ \\
& $-0.297 * * *$ & $-0.302 * * *$ & $(-16.245)$ \\
BOARD & $(-17.075)$ & $(-16.245)$ & $0.029 *$ \\
& $0.030^{*}$ & $0.030^{*}$ & $(1.847)$ \\
11 cash & $(1.956)$ & $(1.889)$ & $-0.090^{* * *}$ \\
& $-0.072^{* * *}$ & & $(-7.547)$ \\
12cash & $(-7.484)$ & & $-0.094 * * *$ \\
& & $-0.077 * * *$ & $(-8.807)$ \\
Year FE & & $(-7.230)$ & Yes \\
Observations & Yes & Yes & 10,112 \\
Number of stkcd & 12,525 & 10,112 & 1,984 \\
R-squared & 2,413 & 1,984 & 0.465 \\
\hline
\end{tabular}

Considering the formation of the lagging item of cash holdings results, this paper reviews the positive aspects of corporate donations, corporate image, and corporate influence from 2011 to 2018 . According to the regression coefficient, the cash holdings of enterprises are negative. The above conclusions are consistent with the main conclusions of this paper.

\subsection{Heterogeneity Analysis}

\subsubsection{Enterprise size Perspective}

Table 4: Heterogeneity Analysis 1

\begin{tabular}{lcccc}
\hline VARIABLES & Small Size & High Size & Small Size & High Size \\
\hline CSR & $0.311^{*}$ & -0.056 & $0.323^{*}$ & -0.118 \\
& $(1.683)$ & $(-0.536)$ & $(1.716)$ & $(-1.158)$ \\
SIZE & $-0.026^{* * *}$ & $-0.006^{*}$ & $-0.037^{* * *}$ & $-0.017^{* * *}$ \\
& $(-5.021)$ & $(-1.657)$ & $(-8.256)$ & $(-5.809)$ \\
\hline
\end{tabular}




\begin{tabular}{|c|c|c|c|c|}
\hline TOBIN & $\begin{array}{c}-0.043 * * * \\
(-18.151)\end{array}$ & $\begin{array}{c}-0.052 * * * \\
(-21.938)\end{array}$ & $\begin{array}{c}-0.038 * * * \\
(-18.762)\end{array}$ & $\begin{array}{c}-0.041 * * * \\
(-19.934)\end{array}$ \\
\hline ROA & $\begin{array}{c}0.108^{* * *} \\
(2.780)\end{array}$ & $\begin{array}{c}0.157 * * * \\
(4.092)\end{array}$ & $\begin{array}{c}0.120 * * * \\
(3.339)\end{array}$ & $\begin{array}{c}0.090 * * \\
(2.549)\end{array}$ \\
\hline LEV & $\begin{array}{c}-0.311 * * * \\
(-17.614)\end{array}$ & $\begin{array}{c}-0.282 * * * \\
(-15.503)\end{array}$ & $\begin{array}{c}-0.271 * * * \\
(-16.680)\end{array}$ & $\begin{array}{c}-0.236 * * * \\
(-13.516)\end{array}$ \\
\hline BOARD & $\begin{array}{c}0.013 \\
(0.942)\end{array}$ & $\begin{array}{c}-0.002 \\
(-0.195)\end{array}$ & $\begin{array}{c}-0.001 \\
(-0.043)\end{array}$ & $\begin{array}{c}0.009 \\
(0.826)\end{array}$ \\
\hline Constant & $\begin{array}{c}1.000^{* * *} \\
(9.189)\end{array}$ & $\begin{array}{c}0.512 * * * \\
(6.473)\end{array}$ & $\begin{array}{l}1.231 * * * \\
(12.987)\end{array}$ & $\begin{array}{c}0.714 * * * \\
(10.638)\end{array}$ \\
\hline Year FE & Yes & Yes & Yes & Yes \\
\hline Industry FE & Yes & Yes & Yes & Yes \\
\hline $\begin{array}{l}\text { Observations } \\
\text { Number of stked }\end{array}$ & $\begin{array}{l}7,522 \\
1,489 \\
\end{array}$ & $\begin{array}{l}7,520 \\
1,029 \\
\end{array}$ & $\begin{array}{l}7,522 \\
1,489 \\
\end{array}$ & $\begin{array}{l}7,520 \\
1,029 \\
\end{array}$ \\
\hline
\end{tabular}

An enterprise in China or even around the world is a profit-oriented organization and an organization with social functions. The value orientation in enterprise management is related to the harmonious development of enterprise and society and profoundly affects people's happiness and social stability. CSR is responsible for the economy, environment, and other subjects consciously undertaken by enterprises. It is also an essential part of realizing high-quality economic development in China, also around the world. CSR is a positive behavior that can produce positive feedback to both the enterprise and the external environment. With the continuous expansion of the enterprise scale, it will have to undertake more social responsibilities. As shown in Table 4, the high size enterprise is, the greater its social responsibility will be, and there is a positive correlation with cash holdings. As Table 4 shows, by observing 7,522 small enterprises and 7,520 large enterprises and comparing the two sets of relevant data. Compared with the two sets of data's SIZE part, we found the value of companies' size bigger, the CSR is higher, which is a significant positive thing. Companies with a larger scale, a higher degree of market concentration, and a relatively standardized corporate governance structure have a stronger awareness and ability to fulfill corporate social responsibility. However, the research on private enterprises with small scale and limited resource acquisition capacity lacks responsibility awareness. The fulfillment of social responsibility will inevitably increase the operating cost of enterprises.

\subsubsection{Lever Perspective}

It is duty-bound for enterprises to assume social responsibilities. The primary purpose of earnings management for enterprises is to meet their own needs. Still, it ignores other stakeholders, and the importance enterprises attach to stakeholders' interests is an important content of corporate social responsibility. CSR is negatively correlated with earnings management, and earnings management can reverse the relationship between CSR and financial leverage. CSR is a management activity carried out by the management and shareholders to balance all stakeholders' expected returns from the perspective of shareholders and corporate stakeholders. The survival and development of enterprises are closely related to them. As shown in Table 5 , the data of 7,519 highly leveraged enterprises. And 7,515 highly leveraged enterprises were observed to compare the two groups of relevant data. By comparing the $L E V$ part of the two sets of data, we find that the value of social responsibility of highly leveraged enterprises is greater than that of low leveraged enterprises.

Therefore, reasonable and adequate earnings management can achieve the expected annual assessment indicators by adjusting earnings and maintaining the stability of stock prices and the company's long-term development.

Table 5: Heterogeneity Analysis 2

\begin{tabular}{lcccc}
\hline VARIABLES & low lev & high lev & low lev & high lev \\
\hline CSR & $-0.340^{*}$ & $0.162^{*}$ & -0.243 & 0.081 \\
& $(-1.869)$ & $(1.802)$ & $(-1.352)$ & $(0.913)$ \\
SIZE & $-0.011^{* * *}$ & $-0.007 * * *$ & $-0.020^{* * *}$ & $-0.018^{* * *}$ \\
& $(-2.844)$ & $(-2.817)$ & $(-5.933)$ & $(-9.184)$ \\
TOBIN & $-0.047 * * *$ & $-0.041^{* * *}$ & $-0.040^{* * *}$ & $-0.033^{* * *}$ \\
& $(-21.311)$ & $(-19.312)$ & $(-21.573)$ & $(-18.101)$ \\
ROA & $0.114 * *$ & $0.112^{* * *}$ & $0.122^{* * *}$ & $0.065^{* * *}$ \\
& $(2.553)$ & $(4.018)$ & $(3.013)$ & $(2.607)$ \\
LEV & $-0.401 * * *$ & $-0.228^{* * *}$ & $-0.383 * * *$ & $-0.176^{* * *}$ \\
& $(-17.288)$ & $(-13.925)$ & $(-18.107)$ & $(-11.576)$ \\
\hline
\end{tabular}




\begin{tabular}{lcccc}
\hline BOARD & 0.011 & 0.003 & 0.005 & 0.006 \\
& $(0.726)$ & $(0.362)$ & $(0.399)$ & $(0.678)$ \\
Constant & $0.745^{* * *}$ & $0.463^{* * *}$ & $0.896^{* * *}$ & $0.683^{* * *}$ \\
& $(8.517)$ & $(8.838)$ & $(12.495)$ & $(15.096)$ \\
Year FE & Yes & Yes & Yes & Yes \\
Industry FE & Yes & Yes & Yes & Yes \\
Observations & 7,519 & 7,515 & 7,519 & 7,515 \\
Number of stkcd & 1,363 & 1,154 & 1,363 & 1,154 \\
\hline
\end{tabular}

\subsubsection{Corporate income}

With the development of social responsibility and social responsibility, Chinese enterprises and investors have a deeper understanding of socially responsible investment. The following is our discussion: the relationship between corporate profits and social responsibility. Companies with good performance in social responsibility do not enjoy a higher premium than similar companies. On the contrary, due to their excellent social responsibility performance, they will increase their expenses, resulting in temporarily lagging profit indicators and investors' abandonment. But as Table 6's 7,515 low-income companies and 7,527 high-income companies show, this is a problem for only a small number of companies. Because with the continuous progress and development of society, this situation will gradually change. In the long run, enterprises with good social responsibility will get more returns, while those with poor social responsibility will encounter more and more troubles. This is consistent with our hypothesis that enterprises with more social responsibility will have more benefits.

Table 6: Heterogeneity Analysis 3

\begin{tabular}{lcccc}
\hline VARIABLES & low income & high income & low income & high income \\
\hline CSR & -0.030 & $-0.468^{* * *}$ & -0.068 & $-0.414^{* *}$ \\
SIZE & $(-0.266)$ & $(-2.870)$ & $(-0.613)$ & $(-2.521)$ \\
& -0.004 & -0.005 & $-0.014^{* * *}$ & $-0.015^{* * *}$ \\
TOBIN & $(-1.264)$ & $(-1.533)$ & $(-5.734)$ & $(-5.531)$ \\
& $-0.050^{* * *}$ & $-0.055^{* * *}$ & $-0.045^{* * *}$ & $-0.046^{* * *}$ \\
ROA & $(-19.256)$ & $(-25.211)$ & $(-19.504)$ & $(-24.135)$ \\
& $0.144^{* * *}$ & $0.180^{* * *}$ & $0.136^{* * *}$ & $0.149^{* * *}$ \\
LEV & $(4.498)$ & $(3.298)$ & $(4.364)$ & $(3.122)$ \\
& $-0.308^{* * *}$ & $-0.319 * * *$ & $-0.255^{* * *}$ & $-0.293^{* * *}$ \\
BOARD & $(-17.935)$ & $(-16.831)$ & $(-15.089)$ & $(-17.129)$ \\
& 0.013 & -0.008 & $0.020^{*}$ & -0.018 \\
Constant & $(1.121)$ & $(-0.577)$ & $(1.767)$ & $(-1.461)$ \\
& $0.477 * * *$ & $0.591 * * *$ & $0.665^{* * *}$ & $0.801 * * *$ \\
Year FE & $(7.493)$ & $(8.123)$ & $(11.725)$ & $(13.570)$ \\
Industry FE & Yes & Yes & Yes & Yes \\
Observations & Yes & Yes & Yes & Yes \\
Number of stkcd & 7,515 & 7,527 & 7,515 & 7,527 \\
\hline
\end{tabular}

\section{CONCLUSION}

By hypothesis and empirical analysis, we believed that enterprises with high corporate social responsibility have a better ability to control risks. It helps them have easier access to direct or indirect financing from other enterprises or banks. So, they tend to have low cash holdings, reducing the cost of cash holdings and financing. For further discussion, the larger the enterprise is, the greater its social responsibilities will be. The CSR of highly leveraged companies is higher than that of lowleveraged companies. The higher the company's income, the greater the social responsibility it has to undertake. Companies that perform their social responsibility well will get more and more rewards in the long run, while those with poor social responsibility will encounter more trouble. More and more investors pay attention to socially responsible investment. Improving CSR is related to China's policies of "people-oriented," 
"harmonious society," "scientific development concept," and "sustainable development". Through the analysis of the impact path of CSR fulfillment on the cash holding level, the role mechanism of CSR fulfillment is clarified, the scope of influencing factors of cash holding level is expanded, and further incremental evidence is added for relevant literature in this field. Due to the relationship between CSR and cash holdings, enterprises can be advocated to actively carry out social responsibility construction, improve the quality of social responsibility fulfillment, optimize the market mechanism, and give full play to the strategic role of resource allocation in the completion of corporate social responsibility.

\section{APPENDIX}

Table 7. Abbreviations corresponding

\begin{tabular}{l|l}
\hline & $\begin{array}{l}\text { The net score of CSR rating based on the MSCI ESG data, measured as total strengths } \\
\text { minus total concerns in five categories: community, diversity, employee relations, } \\
\text { environment, and product, standardized in each Fama-French } 48 \text { industry for each } \\
\text { year. } \\
\text { The natural logarithm of the market value of equity. } \\
\text { Long-term debts divided by total assets. } \\
\text { Income before extraordinary items divided by lagged total assets. } \\
\text { Indicator variables for years. } \\
\text { Indicator variables for industry membership based on two-digit SIC codes. } \\
\text { TOA } \\
\text { TEAR FE scale of the board of directors. } \\
\text { TNDUSTRY FE } \\
\text { Tobin Q value. The sum of equity capitalization and debt capitalization divided by total } \\
\text { assets at the } \\
\text { fiscal year } t \text { end. }\end{array}$ \\
\hline
\end{tabular}

\section{REFERENCES}

[1]Yin, J., Zhang, Y. Institutional Dynamics and Corporate Social Responsibility (CSR) in an Emerging Country Context: Evidence from China. J Bus Ethics 111, 301-316 (2012). DOI : https://doi.org/10.1007/s10551-012-1243-4

[2] A. Ozkan, N. Ozkan. Corporate cash holdings: An empirical investigation of UK companies, Journal of Banking \& Finance, Volume 28, Issue 9, 2004, Pages 2103-2134. DOI: https://doi.org/10.1016/j.jbankfin.2003.08.003.

[3] Tim Opler, Lee Pinkowitz, René Stulz, Rohan Williamson. The determinants and implications of corporate cash holdings, Journal of Financial Economics, Volume 52, Issue 1,1999, Pages 3-46. DOI:

https://doi.org/10.1016/S0304-405X(99)00003-3.

[4] Khalil Jebran, Shihua Chen, Muhammad Zubair Tauni. Principal-principal conflicts and corporate cash holdings: Evidence from China, Research in International Business and Finance, Volume 49,

$$
\text { 2019, Pages 55-70, DOI: }
$$
https://doi.org/10.1016/j.ribaf.2019.02.010.
[5] Nianhang Xu, Qinyuan Chen, Yan Xu, Kam C. Chan. Political uncertainty and cash holdings: Evidence from China, Journal of Corporate Finance, Volume 40, 2016, Pages 276-295, DOI: https://doi.org/10.1016/j.jcorpfin.2016.08.007.

[6] Mishra, S., Modi, S.B. Positive and Negative Corporate Social Responsibility, Financial Leverage, and Idiosyncratic Risk. J Bus Ethics 117, 431-448 (2013). DOI: https://doi.org/10.1007/s10551-012-1526-9

[7] Jiawen Chen, Feng Zhang, Linlin Liu, Lei Zhu. Does environmental responsibility matter in cross-sector partnership formation? A legitimacy perspective, Journal of Environmental Management, Volume 231, 2019, Pages 612-621, DOI: https://doi.org/10.1016/j.jenvman.2018.10.099.

[8] Viral Acharya, Sergei A. Davydenko, Ilya A. Strebulaev, Cash Holdings and Credit Risk, The Review of Financial Studies, Volume 25, Issue 12, December 2012, Pages 3572-3609. DOI: https://doi.org/10.1093/rfs/hhs106

[9] Arouri, M., Pijourlet, G. CSR Performance and the Value of Cash Holdings: International Evidence. J Bus Ethics 140, 263-284 (2017). DOI: https://doi.org/10.1007/s10551-015-2658-5 